\title{
A New Indole Alkaloid Isolated from Tabernaemontana hystrix Steud (Apocynaceae)
}

\author{
Cecilia Silva Monnerat, Jucimar Jorgeane de Souza, Leda Mathias, Raimundo Braz-Filho \\ and Ivo José C. Vieira*
}

\author{
Setor de Química de Produtos Naturais, Universidade Estadual do Norte Fluminense Darcy Ribeiro, \\ 28013-602 Campos dos Goytacazes - RJ, Brazil
}

\begin{abstract}
Um novo alcalóide, denominado histrixnina (1), e cinco alcalóides indólicos conhecidos, ibogamina (2), olivacina (3) e affinina (4), affinisina (5) e $\mathrm{N}_{\mathrm{b}}$-metilaffinisina (6), foram isolados do extrato metanólico das cascas das raízes de Tabernaemontana hystrix. Os triterpenos conhecidos 3 $O$-acetil- $\alpha$-amirina, 3- $O$-acetil- $\beta$-amirina, 3- $O$-acetil-lupeol foram também identificados. As estruturas dos compostos foram elucidadas com base na análise de dados espectroscópicos.
\end{abstract}

A new alkaloid, named hystrixnine (1), and five known indole alkaloids, ibogamine (2), olivacine (3), affinine (4), affinisine (5) and $\mathrm{N}_{\mathrm{b}}$-methylaffinisine (6), were isolated from the root bark of Tabernaemontana hystrix. The known triterpenes $\alpha$-amyrin acetate, $\beta$-amyrin acetate and lupeol acetate were also identified. The structures of the compounds were elucidated based on spectroscopic studies.

Keywords: Tabernaemontana hystrix, Apocynaceae, indole alkaloids, triterpenes

\section{Introduction}

Indole alkaloids exhibit numerous biological activities (such as anti-tumor, anti-microbial, anti-hypertensive and central nervous system stimulant). ${ }^{1}$ They can be found in plants of the Apocynaceae, Rubiaceae, and Loganiaceae families. ${ }^{1,2}$

Among the Apocynaceae, the genus Tabernaemontana is especially rich in indole alkaloids. They are useful chemical markers of the genus, and also have a great value for the classification of the individual species within the genus. ${ }^{3}$ The classification of individual species only on the basis of morphological characters has been difficult, leading to numerous synonyms. ${ }^{4}$

The species Tabernaemontana hystrix Steud. should have the homotypic synonym Tabernaemontana echinata Vell. and Peschiera hystrix (Steud.) A. DC., and the heterotypic synonyms T. collina Gardn. in Hooker, T. fuchsiifolia (A. DC.), Peschiera fuchsiifolia (A. DC.) Miers, T. gaudichaudii A. DC., T. lundii A. DC., Peschiera lundii (A. DC.) Miers, T. gracilis Muell., T. bracteolaris Muell., Peschiera granulosa Miers and Peschiera solandri Miers. ${ }^{4}$ In fact, previous phytochemical studies have been published under the name Peschiera fuchsiifolia (A. DC.) Miers. ${ }^{5,6}$

* e-mail: curcino@uenf.br
As part of our continuing interest in the phytochemical investigation of Tabernaemontana species occurring in Brazil ${ }^{7-9}$ we decided to study $T$. hystrix, a native species of the Atlantic forest in Southeastern Brazil, popularly known as "esperta".

In the present work, we report the phytochemical analysis of the crude methanolic extract of $T$. hystrix, which allowed to characterize the presence of six indole alkaloids ( 1 to $\mathbf{6})$, including the new one named hystrixnine (1), and three triterpenoids. The structures were established by spectrometric techniques, mainly EIMS and 1D and 2D NMR, including comparative analysis with literature values.

\section{Results and Discussion}

Chromatographic purification of T. hystrix root bark methanol extract yielded triterpenes common in plants, including other Tabernaemontana species. ${ }^{10}$ The triterpene acetates were obtained as a mixture of $\alpha$-amyrin acetate, $\beta$-amyrin acetate and lupeol acetate. They were identified by ${ }^{1} \mathrm{H}$ and ${ }^{13} \mathrm{C}$ NMR spectral data compared with literature values. ${ }^{11}$

The known indole alkaloids, ibogamine (2), ${ }^{12,13}$ olivacine (3), ${ }^{14,15}$ affinine (4), ${ }^{5,16,17}$ affinisine $(\mathbf{5})^{5,6,17}$ and $\mathrm{N}_{\mathrm{b}}$-methylaffinisine $(6)^{6}$ were identified on the basis of ${ }^{1} \mathrm{H}$ and ${ }^{13} \mathrm{C}$ NMR spectral data, including homonuclear ${ }^{1} \mathrm{H}-{ }^{1} \mathrm{H}-\mathrm{COSY}$ and heteronuclear ${ }^{1} \mathrm{H}-{ }^{13} \mathrm{C} 2 \mathrm{D}$ shift-correlated 

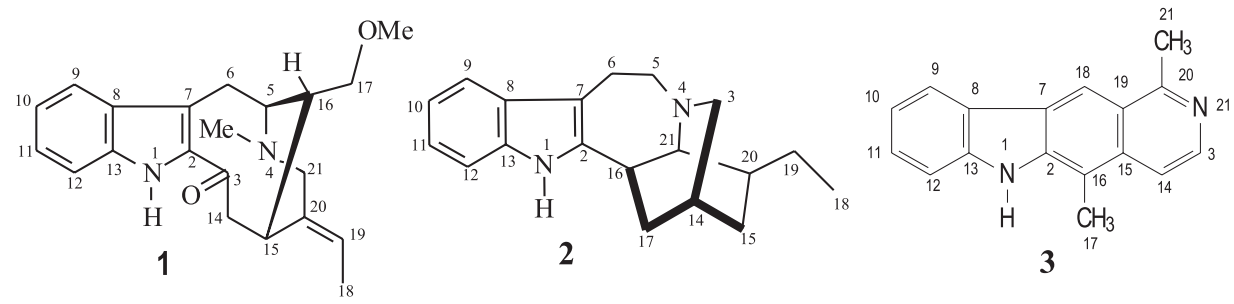
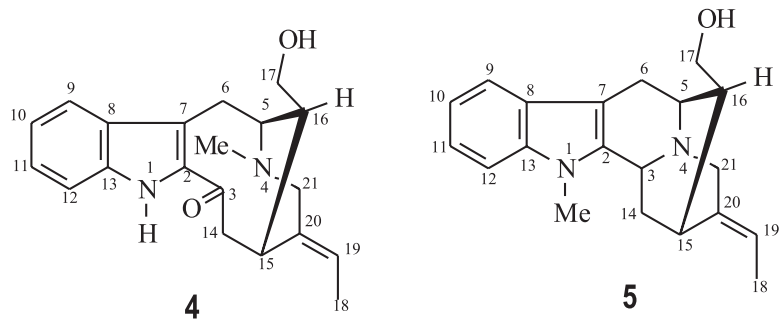

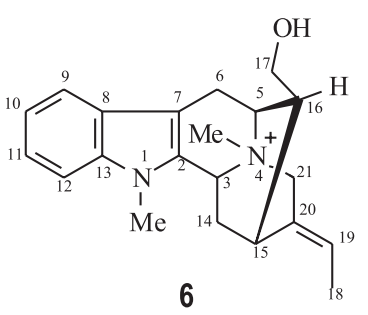

NMR experiments, which were also used to complete and unambiguous ${ }^{1} \mathrm{H}$ and ${ }^{13} \mathrm{C}$ chemical shift assignments. ${ }^{18}$

The UV spectrum of hystrixnine (1) showed absorptions at $\lambda_{\max } 223$ and $282 \mathrm{~nm}$ ( $\varepsilon 42566$ and 6287, respectively) typical of an substituted indole chromophore, ${ }^{8}$ while the IR spectrum revealed bands at $v_{\max } 3360(\mathrm{~N}-\mathrm{H}), 1736$ (conjugated carbonyl ketone group stretching), 2930-2830 (C-H stretching) and 1616, 1591 and $743 \mathrm{~cm}^{-1}(\mathrm{C}-\mathrm{H}$ bending of benzene ring). ${ }^{8}$ The EIMS showed a molecular peak at $\mathrm{m} / \mathrm{z} 338$ daltons $\left([\mathrm{M}]^{+}\right)$which together with ${ }^{1} \mathrm{H}$ and
${ }^{13} \mathrm{C}$ NMR spectral data (Table 1) allowed to deduce the molecular formula $\mathrm{C}_{21} \mathrm{H}_{26} \mathrm{~N}_{2} \mathrm{O}_{2}$ (ten degrees of unsaturation) compatible with corynanthean skeleton. ${ }^{8}$ The principal peaks observed in the EIMS spectrum are in agreement with proposed fragmentation mechanisms summarized in Scheme 1.

Carbon-13 NMR experiments $\left(\left\{{ }^{1} \mathrm{H}\right\}\right.$ and APT) revealed the presence of three methyl groups, four methylenes $\left(\mathrm{sp}^{3}\right)$, eight methines (three $\mathrm{sp}^{3}$ and five $\mathrm{sp}^{2}$ ) and six $\left(\mathrm{sp}^{2}\right)$ quaternary carbon atoms. The ${ }^{1} \mathrm{H}-{ }^{1} \mathrm{H}-\mathrm{COSY}, \mathrm{HMQC}$ and

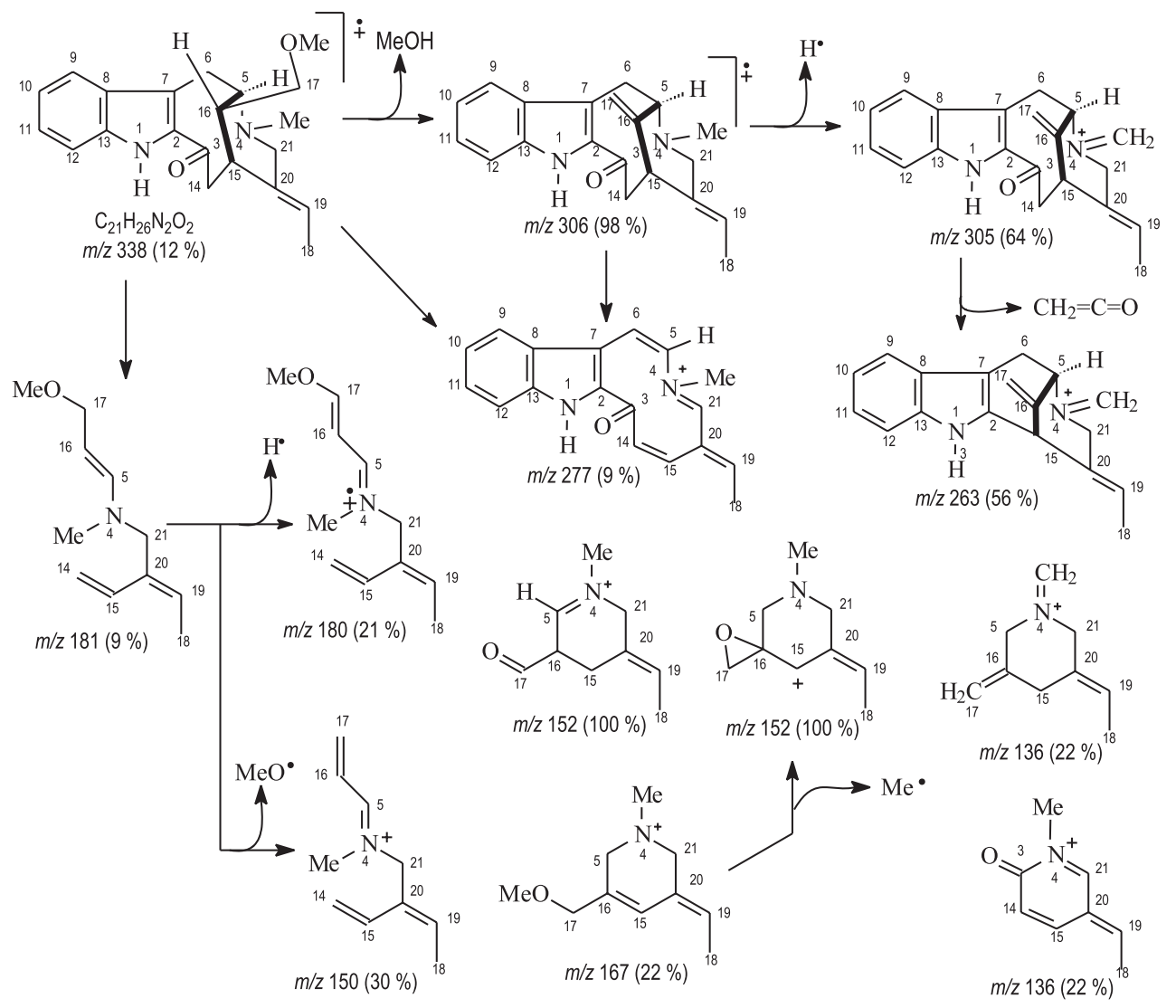

Scheme 1. Fragments proposed to justify the main peaks observed in the ESMS of $\mathbf{1}$. 
Table 1. ${ }^{1} \mathrm{H}(400 \mathrm{MHz})$ and ${ }^{13} \mathrm{C}(100 \mathrm{MHz})$ NMR for hystrixnine (1), including results obtained by heteronuclear 2D shift-correlated HMQC $\left({ }^{1} J_{\mathrm{CH}}\right)$ and $\mathrm{HMBC}\left({ }^{\mathrm{n}} J_{\mathrm{CH}}, \mathrm{n}=2\right.$ and 3$)$ and comparison with $\mathbf{4}$, in $\mathrm{CDCl}_{3}$ as solvent. Chemical shifts $(\delta, \mathrm{ppm})$ and coupling constants $(J, \mathrm{~Hz}$, in parenthesis)*

\begin{tabular}{|c|c|c|c|c|c|c|}
\hline \multicolumn{5}{|c|}{1} & \multicolumn{2}{|r|}{4} \\
\hline & \multicolumn{2}{|c|}{${ }^{1} \mathrm{H}-{ }^{13} \mathrm{C}-\mathrm{HMQC}-{ }^{-1} J_{\mathrm{CH}}$} & \multicolumn{2}{|c|}{${ }^{1} \mathrm{H}-{ }^{13} \mathrm{C}-\mathrm{HMBC}-{ }^{\mathrm{n}} J_{\mathrm{CH}}$} & & \\
\hline $\mathbf{C}$ & $\delta_{\mathrm{C}}$ & $\delta_{\mathrm{H}}$ & ${ }^{2} J_{\mathrm{CH}}$ & ${ }^{3} J_{\mathrm{CH}}$ & $\delta_{\mathrm{C}}$ & $\delta_{\mathrm{H}}$ \\
\hline 2 & 135.43 & - & & $2 \mathrm{H}-6 ; \mathrm{H}-14 \mathrm{a}$ & 136.80 & - \\
\hline 3 & 191.50 & - & $\mathrm{H}-14 \mathrm{~b}$ & H-15 & 194.00 & - \\
\hline 7 & 120.36 & - & H-6 & $\mathrm{HN}-1 ; \mathrm{H}-9$ & 122.00 & - \\
\hline 8 & 128.30 & - & & H-6; H-10; H-12 & 129.60 & - \\
\hline 13 & 136.41 & - & & H-9; H-11 & 138.60 & - \\
\hline 20 & 134.71 & - & $2 \mathrm{H}-21$ & $3 \mathrm{H}-18$ & 136.32 & - \\
\hline \multicolumn{7}{|l|}{$\mathbf{C H}$} \\
\hline 5 & 56.93 & $3.31($ br d, 8.4) & & Мe-4; Н-15; 2H-17; H-21b & 56.97 & $3.06($ br t, 8.3) \\
\hline 9 & 120.48 & $7.70(\mathrm{~d}, 8.1)$ & & $\mathrm{H}-11$ & 121.64 & $7.68($ br d, 8.1) \\
\hline 10 & 120.64 & $7.16(\mathrm{dd}, 8.4,8.1)$ & & H-12 & 121.11 & $7.09(\mathrm{ddd}, 8.3,8.1,1.1)$ \\
\hline 11 & 126.81 & $7.36(\mathrm{dd}, 8.4,8.4)$ & & H-9 & 127.44 & $7.28(\mathrm{ddd}, 8.3,8.3,1.1)$ \\
\hline 12 & 112.19 & 7.49 (br d, 8.4) & & H-10 & 113.40 & 7.40 (br d, 8.3) \\
\hline 15 & 31.60 & 3.07 (br t, 8.8) & $2 \mathrm{H}-14$ & $2 \mathrm{H}-17 ; \mathrm{H}-19 ; \mathrm{H}-21 \mathrm{~b}$ & 31.29 & 3.04 (br t, 8.3) \\
\hline 16 & 38.02 & $1.97(\mathrm{~m})$ & H-5; H-15 & $2 \mathrm{H}-6 ; 2 \mathrm{H}-14$ & 41.27 & $1.89(\mathrm{t}, 6.7)$ \\
\hline 19 & 121.31 & 5.49 (br q, 7.0) & $3 \mathrm{H}-18$ & $2 \mathrm{H}-21$ & 122.50 & 5.49 (br q, 6.7) \\
\hline \multicolumn{7}{|l|}{$\mathrm{CH}_{2}$} \\
\hline \multirow[t]{2}{*}{$6^{2}$} & 19.34 & $3.54(\mathrm{~m})$ & $\mathrm{H}-5$ & & 20.60 & $3.34(\mathrm{~m})$ \\
\hline & & $3.48(\mathrm{~m})$ & & & & $3.29(\mathrm{~m})$ \\
\hline \multirow[t]{2}{*}{14} & 43.50 & $3.33(\mathrm{~m})$ & H-15 & & 44.30 & $3.25(\mathrm{dd}, 12.6,9.7)$ \\
\hline & & $2.67(\mathrm{dd}, 12.8,7.7)$ & & & & $2.45(\mathrm{dd}, 12.6,6.7)$ \\
\hline \multirow[t]{2}{*}{17} & 67.44 & $3.62(\mathrm{dd}, 8.0,2.2)$ & & H-5; H-15 & 65.61 & $3.41(\mathrm{dd}, 6.2,1.1)$ \\
\hline & & $3.59(\mathrm{dd}, 8.0,2.2)$ & & & & \\
\hline \multirow[t]{2}{*}{21} & 52.04 & $3.70($ br d, 13.9) & & MeN-4; H-5; H-15; H-19 & 53.27 & $3.50($ br d, 13.7) \\
\hline & & $3.04(\mathrm{~d}, 13.9)$ & & & & $2.83(\mathrm{~d}, 13.7)$ \\
\hline \multicolumn{7}{|l|}{$\mathrm{CH}_{3}$} \\
\hline 18 & 12.10 & $1.70(\mathrm{dd}, 7.0,2.2)$ & H-19 & & 12.20 & $1.65(\mathrm{dd}, 6.7,1.9)$ \\
\hline $\mathrm{MeN}$ & 41.81 & $2.57(\mathrm{~s})$ & & & 42.30 & $2.41(\mathrm{~s})$ \\
\hline $\mathrm{MeO}$ & 50.74 & $3.47(\mathrm{~s})$ & & & - & - \\
\hline $\mathrm{HN}-1$ & - & 9.32 (br s) & & & - & 9.15 (br s) \\
\hline
\end{tabular}

*Number of hydrogens bound to carbon atoms deduced by comparative analysis of ${ }^{1} \mathrm{H}$ - and APT- ${ }^{13} \mathrm{C}$ NMR spectra. Chemical shifts and coupling constants $(J)$ obtained of $1 \mathrm{D}{ }^{1} \mathrm{H}$ NMR spectrum. Superimposed ${ }^{1} \mathrm{H}$ signals are described without multiplicity and chemical shifts deduced by HMQC, HMBC and ${ }^{1} \mathrm{H}-{ }^{1} \mathrm{H}-\mathrm{COSY}$ spectra. All ${ }^{1} \mathrm{H}$ and ${ }^{13} \mathrm{C}$ chemical shift assignments of 1 were also based on homonuclear ${ }^{1} \mathrm{H}-{ }^{1} \mathrm{H}-\mathrm{COSY}$ and heteronuclear 2D shift-correlated HMQC $\left({ }^{1} J_{\mathrm{CH}}\right)$ and $\mathrm{HMBC}\left({ }^{\mathrm{n}} J_{\mathrm{CH}}, \mathrm{n}=2\right.$ and 3) NMR.

HMBC experiments established geminal and vicinal hydrogen interactions as well as direct $\left({ }^{1} J_{\mathrm{CH}}\right)$ and two and three bond correlations between carbon and hydrogen atoms in the structure (Table 1). These data revealed that $\mathbf{1}$ is closely related to affinine (4), differing by the presence of methoxyl group linkage at $\mathrm{C}-17$. The presence of the indole nucleus was clearly indicated by the ${ }^{1} \mathrm{H}$ and ${ }^{13} \mathrm{C}$ aromatic signals (Table 1 ). Typically the ${ }^{1} \mathrm{H}$ NMR revealed two singlet signals at $\delta_{\mathrm{H}} 3.47(\mathrm{MeO}-17)$ and $2.57(\mathrm{MeN}-4)$ and double doublet signal at $\delta_{\mathrm{H}} 1.70(J=7.0$ and $2.2 \mathrm{~Hz}$, $3 \mathrm{H}-18$ linkage at $\left.\mathrm{sp}^{2} \mathrm{CH}-19\right)$ corresponding to methyl groups. Through analysis of the HMBC spectrum these signals were assigned by corresponding cross-peaks, due to heteronuclear spin-spin coupling via three $\left({ }^{3} J_{\mathrm{CH}}\right)$ bonds, two methyl groups linked to the allylic Me- 18 and N-4 (aliphatic $\mathrm{N}_{\mathrm{b}}$ ), respectively: $i$ ) Me-18 $\left(\delta_{\mathrm{H}} 1.70\right)$ with C-20 $\left.\left(\delta_{\mathrm{C}} 134.71\right) ; \mathrm{ii}\right)$ and MeN-4 $\left(\delta_{\mathrm{H}} 2.57\right)$ with both $\mathrm{CH}-5\left(\delta_{\mathrm{C}}\right.$
56.93) and $\mathrm{CH}_{2}-21\left(\delta_{\mathrm{C}}\right.$ 52.04). The ketone group localized at position $\mathrm{C}-3$ was confirmed by correlations with $\mathrm{H}-14 \mathrm{~b}$ $\left[\delta_{\mathrm{H}} 3.33\left({ }^{2} J_{\mathrm{CH}}\right)\right]$ and $\mathrm{H}-15\left[\left(\delta_{\mathrm{H}} 3.07\left({ }^{3} J_{\mathrm{CH}}\right)\right]\right.$. The presence of methoxyl group was confirmed by ${ }^{1} \mathrm{H}$ NMR and ${ }^{13} \mathrm{C}$ NMR spectra by presence of the signals at $\delta_{\mathrm{H}} 3.47$ (s) and $\delta_{\mathrm{C}}$ 50.74 (Table 1). The complete analysis of this HMBC spectrum in combination with additional NMR spectral data also allowed the identification of a skeleton as that of the indole alkaloid affinine $(4)^{5,16,17}$ and the total ${ }^{1} \mathrm{H}$ and ${ }^{13} \mathrm{C}$ chemical shift assignments, as summarized in Table 1. Thus, the new alkaloid corynanthean skeleton isolated from Tabernaemontana hystrix was characterized as $\mathbf{1}$, named hystrixnine.

In accordance with the revision published by Leeuwenberg, ${ }^{4}$ the alkaloid series isolated in this study from $T$. hystrix are closely related to those previously reported from Peschiera fuchsiifolia: decarbomethoxy- 
voamine, demethylvoacamine, voacamidine, perivine, 16-epiaffinine, voacangine hydroxyindolenine, fuchsiaefoline, 12-methoxy- $\mathrm{N}_{\mathrm{b}}$-methylvoachalotine and 12-methoxy- $\mathrm{N}_{\mathrm{b}}$-methylvoachalotine ethyl ester (reported by Braga and co-workers). ${ }^{5,6}$ The similarity of the alkaloids reported in this work in comparison with those from two other Brazilian Tabernaemontana species is remarkable. From T. solanifolia were reported the alkaloids: isovoacangine, isovoacristine, coronaridine, voacangine, voacangine hydroxyindolenine, heyneanine, voacamine, voachalotine and 12-methoxy-Nb-methylvoachalotine [reported under the name Peschiera campestris (Rizz.) Rizz. by Gower et al. $]^{19}$ and P. laeta were described the alkaloids: coronaridine, voacangine, isovoacangine, 19-(S)-heyneanine, isovoacristine, 3-oxoisovoacangine, ibogaine, iboxygaine, tabersonine, apparicine, vobasine, $\mathrm{N}_{\mathrm{b}}$-methylvoachalotine, voacamine, conodurine and tabernamine [reported under the name T. laeta (Mart.) by Medeiros and co-workers]. ${ }^{7-9}$ This similarity might point to a close taxonomic relationship of these recognized species.

\section{Experimental}

\section{General}

${ }^{1} \mathrm{H}$ NMR and ${ }^{13} \mathrm{C}$ NMR: At Jeol Eclipse spectrometer operating at $400 \mathrm{MHz}$ and $100 \mathrm{MHz}$, respectively, in $\mathrm{CDCl}_{3}$, using the residual solvent signals as internal standard (Table 1).

\section{Plant materials}

The root bark of Tabernaemontana hystrix Steud. was collected in March 2002 at Varre e Sai, Rio de Janeiro State, Brazil, and identified by Dr. A. J. M. Leeuwenberg of the Agricultural University of Wageningen, The Netherlands. A voucher specimen (WAG) is deposited at the herbarium of the Agricultural University of Wageningen, Netherlands.

\section{Extraction and isolation}

Dried and powdered root bark $(0.92 \mathrm{~kg})$ from T. hystrix Steud. was extracted at room temperature using methanol, furnishing after solvent evaporation, crude methanol extracts $(40.0 \mathrm{~g})$.

$23.0 \mathrm{~g}$ of the methanol extract was chromatographed on a $\mathrm{Si}$ gel column and eluted with a gradient of $\mathrm{MeOH}$ in $\mathrm{CH}_{2} \mathrm{Cl}_{2}$, yielding 11 fractions. The fractions 1-3 (460 mg) was recrystallizated from hexane to furnish a mixture of the three triterpenes ( $180 \mathrm{mg}) \alpha$-amyrin acetate, $\beta$-amyrin acetate and lupeol acetate; fraction $5(940 \mathrm{mg})$ furnished 2 (58 mg); fraction 8 (1.58 g) was rechromatographed on a Si gel column using a gradient of $\mathrm{MeOH}$ in $\mathrm{CH}_{2} \mathrm{Cl}_{2}$ affording 5 (73 mg); fraction $9(1.36 \mathrm{~g})$ was rechromatographed in the same way, yielding the alkaloids $\mathbf{3}(73 \mathrm{mg})$, $4(26 \mathrm{mg})$ and $6(11 \mathrm{mg}) .2 .6 \mathrm{~g}$ of fraction 10 was rechromatographed on a Si gel column using a gradient of $\mathrm{MeOH}$ in $\mathrm{CH}_{2} \mathrm{Cl}_{2}$ furnishing 06 fractions, of which, fraction $4(54 \mathrm{mg})$ furnished the alkaloid $\mathbf{1}(7.9 \mathrm{mg})$ after rechromatography with a mixture of $\mathrm{MeOH}$ in $\mathrm{CH}_{2} \mathrm{Cl}_{2}$.

The four alkaloids 2-6, as well as three triterpenes were identified by the analysis of ${ }^{1} \mathrm{H}$ and ${ }^{13} \mathrm{C}$ NMR and comparison with literature values. ${ }^{11-17}$

hystrixnine (1). Amorphous solid; $[\alpha]^{25}{ }_{\mathrm{D}}-100^{\circ}(\mathrm{MeOH}$, $c$ 0.66); IR (KBr) $v_{\max } / \mathrm{cm}^{-1} 1736(\mathrm{C}=\mathrm{O}), 1616,1591,743$ (aromatic ring); $\mathrm{UV} \lambda_{\max } / \mathrm{nm}\left(\mathrm{CH}_{3} \mathrm{OH}\right) 223(\varepsilon 42566), 282(\varepsilon$ 6287). EIMS: Scheme $1 ;{ }^{1} \mathrm{H}$ NMR and ${ }^{13} \mathrm{C}$ NMR: Table 1.

\section{Acknowledgements}

The authors are grateful to Fundação de Amparo à Pesquisa do Estado do Rio de Janeiro (FAPERJ) for grants and to Conselho Nacional de Desenvolvimento Científico (CNPq-Brazil) for a research fellowship and grants.

\section{References}

1. Verpoorte, R. In Alkaloids: Biochemistry, Ecology and Medicinal Applications; Roberts, M. F.; Wink, M., eds.; Plenum Press: New York, 1998.

2. Bruneton, J.; Pharmacognosy, Phytochemistry, Medicinal Plants, Lavoisier, Intercept Ltd.: Andover, UK, 1995.

3. Van Beek, T.A.; Verpoorte, R.; Svendsen, A.B.; Leeuwenberg, A.J.M.; Bisset, N.G.; J. Ethnopharmacol. 1984, 10, 1.

4. Leeuwenberg, A.J.M.; A Revision of Tabernaemontana. Vol. 2. The New World Species and Stemmadenia. Royal Botanic Gardens, Kew: UK, 1994.

5. Braga, R.M.; Leitão-Filho, H.; Reis, F.A.M.; Phytochemistry 1984, 23, 175.

6. Braga, R.M.; Reis, F.A.M.; Phytochemistry 1987, 26, 833.

7. Medeiros, W.L.; Vieira, I.J.C.; Mathias, L.; Braz-Filho, R.; Leal, K.Z.; Rodrigues-Filho, E.; Schripsema, J.; Magn. Reson. Chem. 1999, 37, 676.

8. Medeiros, W.L.; Vieira, I.J.C.; Mathias, L.; Braz-Filho, R.; Schripsema, J.; J. Braz. Chem. Soc. 2001, 12, 368.

9. Medeiros, W.L.; Vieira, I.J.C.; Mathias, L.; Braz-Filho, R.; Ann. Magn. Reson. 2003, 1, 59.

10. Schripsema, J.; Hermans-Lokkerbol, A.; Van der Heijden, R.; Verpoorte, R.; Baerheim Svendsen, A.; J. Nat. Prod. 1986, 49, 733. 
11. Ahmad, V. U.; Atta-ur-Rahman; Handbook of Natural Products Data. Vol. 2. Pentacyclic Triterpenoids; Elsevier: Amsterdam, 1994.

12. Wenkert, E.; Cochran, D.W.; Gottlieb, H.E.; Hagaman, E.W.; Braz Filho, R.; Matos, F.J.A.; Madruga, M.I.L.M.; Helv. Chim. Acta 1976, 59, 2437.

13. Shamma, M.; Hindenlang, D.M.; Carbon-13 NMR Shift Assignments of Amines and Alkaloids, Plenum Press: New York, 1979.

14. Ahond, A.; Popat, C.; Potier, P.; Tetrahedron 1978, 34, 2385.
15. Azoug, M.; Loukaci, A.; Richard, B.; Nuzillard, J.M.; Moreti, C.; Zeches-Hanrot, M.; Men-Olivier, L.; Phytochemistry 1995, 39, 1223.

16. Araujo, A.R.; Kascheres, C.; Fujiwara, F.; Marsaioli, A.J.; Phytochemistry 1984, 23, 2359.

17. Lounasmaa, M.; Tolvanen, A.; Heterocycles 1986, 24, 3229.

18. Claridge, T.D.W.; High-Resolution NMR Techniques in Organic Chemistry, Pergamon: Amsterdam, 1999.

19. Gower, A.E.; Pereira, B. da S.; Marsaioli, A.J.; Phytochemistry 1986, 25, 2908. 